\title{
Social media use for educational purposes: Systematic Literature Review in higher education of Middle East Countries (MEC)
}

\author{
Mohammed Abdullatif Almulla \\ Faculty of Education, Department of Curriculum and Instruction, University of King Faisal, Alahsa 31982, Saudi \\ Arabia, Email: maalmulla@kfu.edu.sa
}

\begin{abstract}
This research provided a systematic literature review of 205 studies regarding social media (SM) use for education purposes in higher educationof Middle East Countries (MEC)from 1999 to 2020. The present work primarily aims to present an extensive and systematic review of literature concerning social media used among universities' students. Therefore, this research conducted an analysis of studies dedicated of using (SM) for educational purposes on the basis of certain dimensions namely, journal, country, author, year of publication, research methods, and type of respondents. Based on the obtained findings, the use of quantitative and survey research methods (70.3) dominate this field of study compared to qualitative research methods (5.8) and mixed methods (23.9).Moreover, the findings obtained revealed that the interest on the topic has shown an increasing trend over recent years that it has ultimately become a well-known topic for academic research in the future. Nevertheless, to boost and enhance the using (SM) for educational purposes, it is important that future studies apply considerable use of theoretical and methodological approaches like the qualitative methods to examine the factors it will encourage students to use (SM).
\end{abstract}

Key words: Social Media Use, Higher Education, Systematic Literature Review, Middle East Countries (MEC)

\section{INTRODUCTION}

Social media is widely considered as facilitating active collaborative learning among research students. However, there is a lack of research on this topic in Saudi Arabia higher education. Thus, the present research attempted to minimize the literature gap by examining the use of social media for active collaborative learning and engagement to affect learning performance of research students.Social media ease of use and usefulness helps students to become more active, create understanding and discussion among peers, supervisors, instructor and experts, the receipt of expert guidance, and problem fixing abilities [1]. Perceived ease of use and perceived usefulness were statistically significant predictors for satisfaction. Statistically, satisfaction is significantly higher for users who have more friends and who interact with more students compared to those who have fewer friends and less interactivity [2].Social media used as social learning resources provide opportunities for high school students to validate and appreciate creative work, support towards peer alumni, and provide and obtain related school support. Factors investigated in the context of higher education include faculty use $[3,4,5]$, student engagement $[6,7,8,9]$, impact on as well as relation to academic achievement [6,9]. Yang et al. [10] concluded that university students showed a more positive attitude toward peer interaction and academic achievement through interactive blogs. Active collaborative learning can occur on social media, as they can be used to help individuals work together to complete a collective objective [11]. In addition to this, social media use facilitates positive relationship between the learning performance and satisfaction of research students [12]. Furthermore, $[13,14]$ reported a positive relationship between students learning performance and Facebook usage.Students use social media for socializing activities and not for interactivity to active collaborative learning, engagement and academic purpose [12]. According to [12], a research model of antecedents and consequences of social media was used but results indicated a higher perceived risk of using social media to waste time and reduce motivation to learn. Moreover, as highlighted by Wang et al.[15], various scholars have indicated that time allocated in using social networking was heavily affected. It is likely that most Saudi Arabia higher education students use social media and spend many hours checking social media, and that there is an adverse aspect to research student's utilization of social media. Research students use social media for learning which has negative effect on their concentration like time spent [16]. There has been a vast amount of research on social media networks. In recent years, a new stream of research in this field has started gaining attention in regard to social media usage. Research on social media has been predominantly conducted in fields such as privacy 
[17], psychology [15], cultural and social [18]. Nevertheless, there is lack of studies [12, 16, 19] that have researched understanding the use of social media as tools of effective learning performance through active collaborative learning in higher education and how it can elevate the quality of learning in Saudi Arabia higher education institutions. So far, focus has been placed in developed countries such as the USA, Australia and the UK. However, this research will describe and discuss studies in higher education of Middle East Countries (MEC). Additionally, the few studies which have investigated social media acceptance and adoption have neglected significant parts of inherent nature of social media which is related to both interactive and perceptual factors of social media use $[16,17]$. Thus, this research is important and will an extensive and systematic review of literature concerning social media used among universities' students in higher education of Middle East Countries (MEC). In addition, while there are many social media models there is no model in evaluating learning performance and satisfaction of research students via using social media for active collaborative learning and engagement in higher education of (MEC), representing a gap in this area. Thus, the research problem in this study will be to investigate and explore the previous studies that affect and influence to academic performance of students, with satisfaction of using social media in (MEC).

\section{RELATED WORK}

The social media activity logs also show an increase in learner engagement in the course, particularly with an assessment task. Recent evidence [20] has shown that social media is one of the best ways to enhance communication, inculcate a more positive learning attitude, motivate students to learn, encourage them to take their learning tasks more seriously and increase their social capital via virtual interactions.The engagement is dependent upon the interactions between the environment and the individual to ensure social and academic interactions between the research group member and the class in order to modify student awareness and engagement $[21,22]$. Extensive use of social media has shed light on the various ways in which individuals interact with others through knowledge sharing, and as a result, integrate online interaction into their day to day lives [23,24]. The use and benefits of social media for academic gain appears to be an area of interest for many researchers in education and social sciences. Many researchers have addressed different areas of using social media at various academic and social levels. The available literature on social media put forward useful ideas for implementing in higher education [1]. Social media is being used to enhance communication among and between learners and their communities. The connection between collaborative learning, engagement and learning performance was supported [6]. Social media has been widely accepted in the social science domain because of its benefits, flexibility and ability to address diverse academic and social problems. Research exploring social media has suggested suitable ways of its implementation in higher education [1]. Social media is looked upon as a vehicle for transmitting new knowledge between the learners and their communities. A developed social media for college students aimed at enhancing both active collaborative learning and social interaction reveals that making social media tools a part of traditional learning is attractive to students and can motivate participation in the learning process. In other similar studies, a social bookmarking tool [25], using the process and virtual structure put in place for the benefit of students' motivation and collaborative group learning process between peers, instructors and owners is called social media to support active collaborative learning (SSCL).

\subsection{Types of Social Media Use in Higher Education}

Social media definition has been constantly changing with potentially enhanced features to meet user demands and specifications. The current internet, sometimes called Web 2.0, allows for more interaction, collaboration and modification by its users [26] than its predecessor, web 1.0, which was more stagnant in character and less interactive. They consist of numerous and diverse items as listed in [26], such as active collaborative learning via Facebook, Blogs and YouTube.Higher education has drawn widespread attention from the research community on the implementation of social media curriculum for teaching and learning purposes. Active collaborative learning and motivating cognitive skills reflection and metacognition is a fundamental of social media for active collaborative learning in higher education [27]. The connection between Twitter and Blog [6] and other social media tools $[28,29]$ are for active collaborative learning and engagement to affect learning performance of research students in higher education. Table 1 shows the definitions content and the main function of social media tools of this research. 
Table 1: Social Media Platforms

\begin{tabular}{|l|l|}
\hline \multicolumn{1}{|c|}{ Platform } & \multicolumn{1}{c|}{ Main Function } \\
\hline Facebook & $\begin{array}{l}\text { A platform that allows user to upload information such as photos, videos, notes and to connect with } \\
\text { friends from various walks of life. }\end{array}$ \\
\hline LinkedIn & $\begin{array}{l}\text { Creating professional links and sharing vital information with intellectual groups from time to time } \\
\text { that would not have been known to those that did not belong to the group connections. }\end{array}$ \\
\hline Blog & $\begin{array}{l}\text { Brings together potential future contributors on a phenomena, blogs are frequently provided by } \\
\text { hosting services such as Blogs that create interactivity. }\end{array}$ \\
\hline Twitter & $\begin{array}{l}\text { Allows users to pursue their interests by receiving instantaneous updates from friends, industry } \\
\text { experts, preferred celebrities, and activities around the world by creating social conversations. }\end{array}$ \\
\hline MySpace & $\begin{array}{l}\text { Engaging in numerous forms of online activity including webcasting, blogging, instant messaging, } \\
\text { chatting, music and gaming. }\end{array}$ \\
\hline YouTube & $\begin{array}{l}\text { Uploading and sharing of video content and allowing for response or deliberations concerning } \\
\text { them. Used for video hosting. }\end{array}$ \\
\hline
\end{tabular}

Source: Researcher's own construct

\section{THEORETICAL FRAMEWORKS AND REFERENCE THEORIES}

Students unable to find a cognitive balance and who have tried to become accustomed to obtaining equilibrium cognition and supported the learners to build the knowledge as the theory of social constructivist of [30] that see in social media network interactive and the perspective of allotment of knowledge and information or discuss with others. Thus this study will use Constructivism [30] in support of the basic idea that learning is an active, constructive process. Based [31] model for developing an interactive platform to implement constructivist learning higher education is shown in Figure 1.

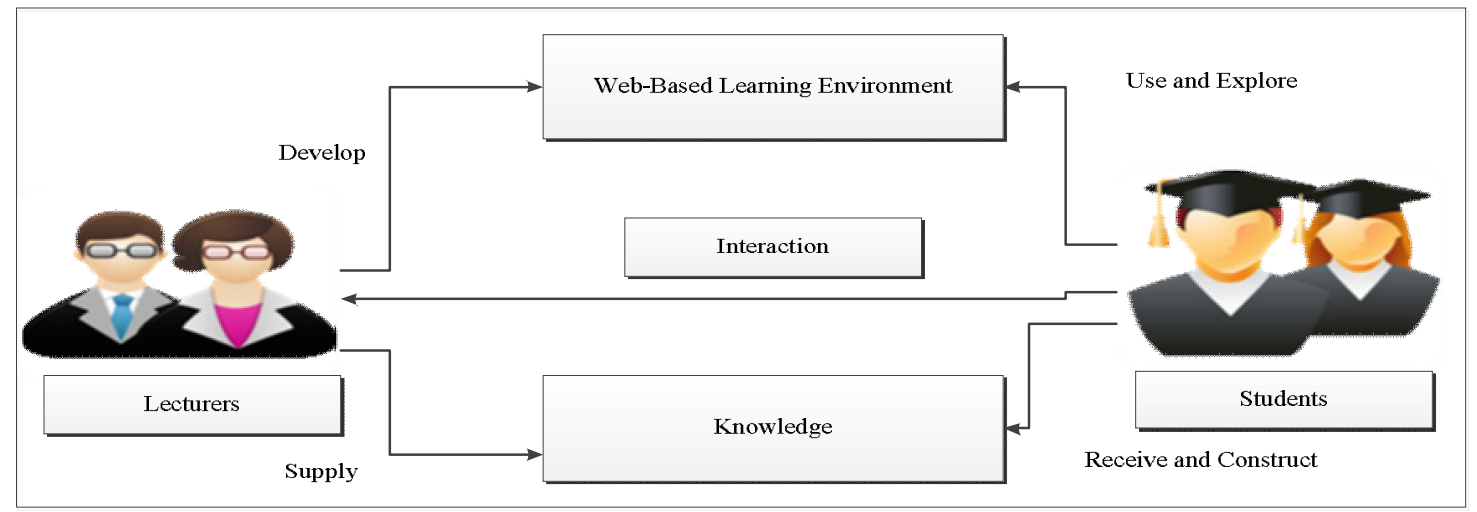

Figure 1: Constructivist Educational Model adapted [9]

This study will also use Technology Acceptance Model (TAM) as introduced by Davis et al. [32]. This model focuses on investigating the factors that influence individuals' social media using a specific innovation or service [32]. Several studies found that perceived ease of use and perceived usefulness have a significant role in influencing satisfaction and individuals' intention in using a new technology [18, 6]. See figure 2.

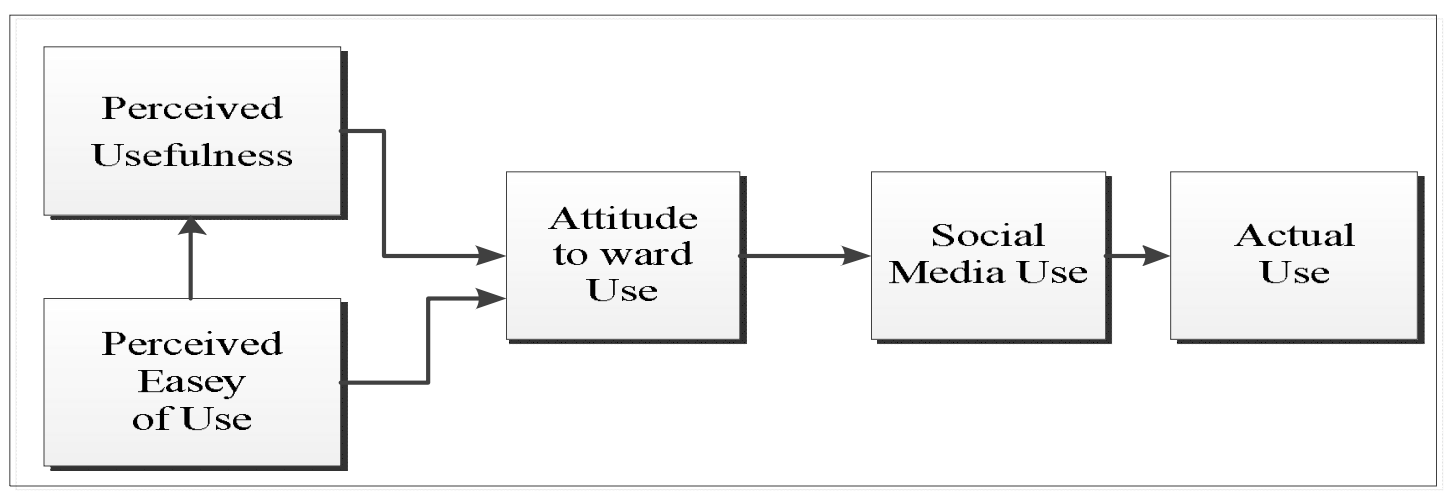

Figure 2: Technology Acceptance Model (TAM) 
The social media to support active collaborative learning (SSCL) for enhancing information social media was designed based on social constructivist theory as tools for promotion of the students' knowledge construction and to find interaction between students with peers and students with teachers and additional experienced experts in the process. In the case of the learner who is unable to construct the knowledge, social media would be used. In addition, social media was able to enhance the cognitive and met cognition requirements [33]. See figure 3 .

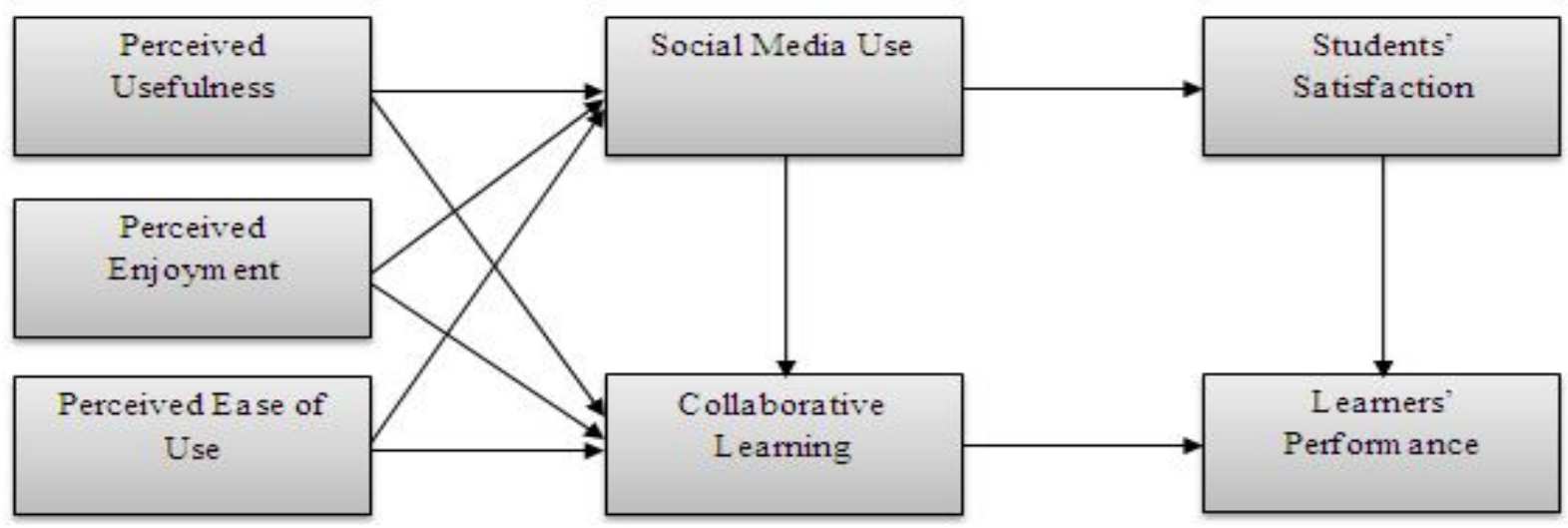

Figure 3: The research model with hypotheses[33]

According to [14] active collaborative learning and engagement experience in the social media environment is better than face-to-face learning. Comparatively, empirical evidence suggested that students on campus needed more support in utilizing complementary social media active collaborative learning options in comparison with face-to-face conferences, also, Lecturers may have significant roles in supporting students when moving to the utilization of social media in assisting brief questions, solutions and coordination in showing such media for active collaborative learning and engagement [34, 6]. See figure 4.

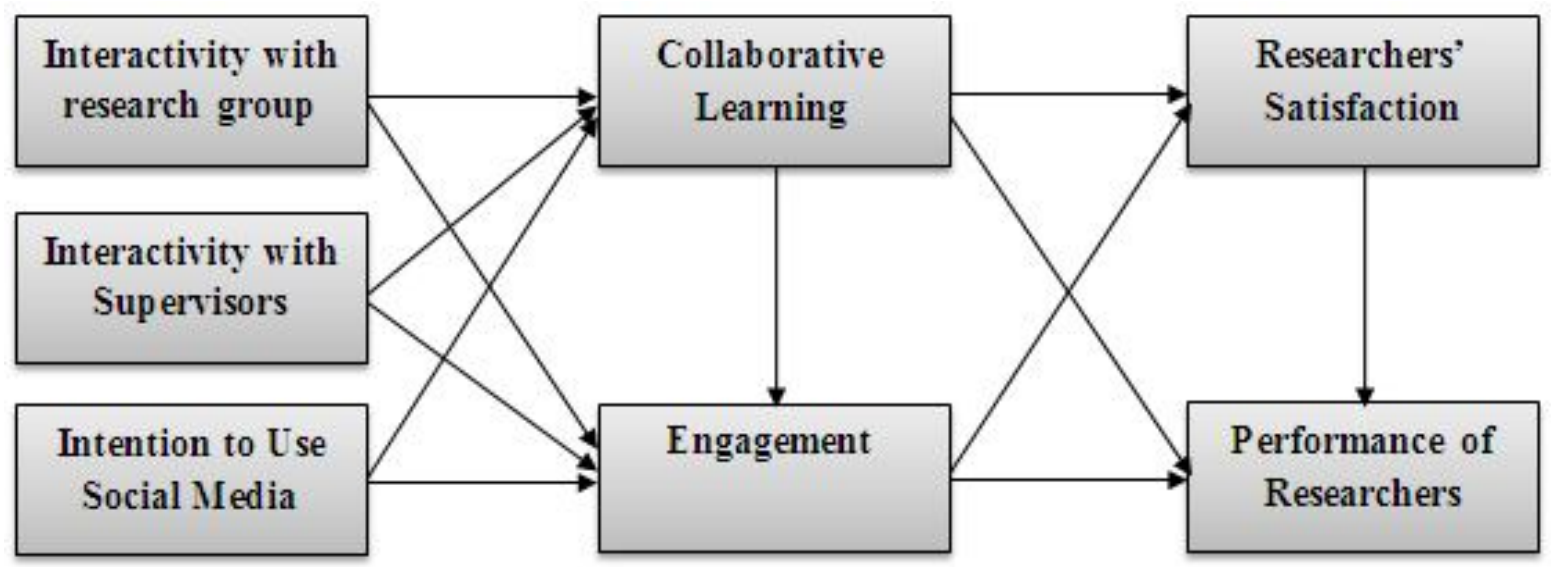

Figure 4: Conceptual framework and hypotheses[14]

\section{RESEARCH METHOD}

The concept of information system (IS)and information technology (IT) continuance can be understood as a combination of three fields: IS/IT, service management and marketing. Accordingly, this study reviewed the literature on IS continuance in databases related to these three fields on the social media use, including: ScienceDirect, Springer, Emerald Fulltext, Taylor \& Francis, Wiley InterScience, and Ingenta Journals. The Google
Scholar search engine was also used to ensure the coverage of publications in other databases. It backward by reviewing the citations for the articles identified to find more articles. The following criteria were used to search these sources and select the papers:

- Journals papers, conference papers, doctoral dissertations, Master's theses, and unpublished working papers were excluded because academics and practitioners usually use journals to obtain information and 
disseminate new findings. Then, journals represent the highest level of research;

- Information systems and information technology search terms from the basis of using social media were employed to search for the titles and abstracts of books and papers.

The present work primarily aims to present an extensive and systematic review of literature concerning IS/IT use from the social media use. The present situation in the field is determined by identifying the lines of inquiry that is lacking investigative activity and this necessitates answering the following research questions;

1. What are the research issues that have been addressed in IS literature on the social media use? Which journal, by whom, where and when was it published?

2. What are the theoretical frameworks/ models/theories that have been employed in studies dedicated to the topic?

3. What are the research methods that have been utilized?

\section{FINDINGS}

The findings of the review are provided in this section. First, the answers to the above research questions are answers. What are the research issues that have been addressed in IS/ IT literature on the social media use?Since 1992, when Davis, et al. [32] develop a Motivational Model (MM) to using technology, as well as the Technology Acceptance Model (TAM) [32], noted there has been a steady rise in research output related to the IT and IS. This search resulted in 145 related articles published between 2014 and 2020. Thus, in this research all articles were selected. The articles were analyzed by the year of publication, journal, country and author. This particular analysis provides guidelines for pursuing rigorous research on using IS/ IT from the social media use. The details are presented below.

\subsection{Distribution by the Year of Publication}

The distribution of articles from 1999 to 2020 is shown in Table 2. From the data, it is clear that there is an upward trend in the number of using social media for education purposes in higher education of Middle East Countries (MEC). From this trend, it would appear that the attention is given to use (SM) continuance has risen over time, and remains an important area of research. For example, it was found that more than half 132 studies were published in the last four years i.e., from 2015 to 2020 . See Tables 2.

Table 2: Distribution by the Year of Publication

\begin{tabular}{|c|c|c|c|c|c|}
\hline Year & $\begin{array}{c}\text { Article } \\
\text { Count }\end{array}$ & Year & $\begin{array}{c}\text { Article } \\
\text { Count }\end{array}$ & Year & $\begin{array}{c}\text { Article } \\
\text { Count }\end{array}$ \\
\hline 2020 & 7 & 2013 & 14 & 2006 & 2 \\
\hline 2019 & 32 & 2012 & 6 & 2005 & 1 \\
\hline 2018 & 14 & 2011 & 13 & 2004 & 0 \\
\hline 2017 & 32 & 2010 & 11 & 2003 & 1 \\
\hline 2016 & 27 & 2009 & 4 & 2002 & 1 \\
\hline 2015 & 20 & 2008 & 6 & 1999 & 1 \\
\hline 2014 & 13 & 2007 & 0 & Total & 205 \\
\hline
\end{tabular}

\subsection{Distribution by Journal}

Table 3 shows the outcome results based on distribution of articles by the journal where authors published. The majority papers were published on Egitim Arastirmalari Eurasian Journal of Educational Research (12 papers) also, Turkish Online Journal of
Educational Technology (12 papers). As well as other papers was published on 22 various journals see Table 3. And other 89 papers published on 89 various journals. The result and analysis depends on scope of journals.

Table 3: Distribution by Journal

\begin{tabular}{|l|c|l|c|}
\hline \multicolumn{1}{|c|}{ Journal Nournal } & No \\
\hline $\begin{array}{l}\text { Egitim Arastirmalari Eurasian Journal Of } \\
\text { Educational Research }\end{array}$ & 12 & Bilgi Dunyasi & 4 \\
$\begin{array}{l}\text { Turkish Online Journal Of Educational } \\
\text { Technology }\end{array}$ & 12 & Cultural Studies Of Science Education & 4 \\
\hline Higher Education & 9 & Elementary Education Online & 4 \\
\hline Kuram Ve Uygulamada Egitim Bilimleri & 9 & $\begin{array}{l}\text { Journal Of Mazandaran University Of Medical } \\
\text { Sciences }\end{array}$ & 2 \\
\hline Computers And Education & 8 & Journal Of Religion And Health & 2 \\
\hline Computers In Human Behavior & 8 & Procedia Computer Science & 2 \\
\hline
\end{tabular}




\begin{tabular}{|l|c|l|c|}
\hline Egitim Ve Bilim & 3 & Procedia Social And Behavioral Sciences & 2 \\
\hline $\begin{array}{l}\text { Eurasia Journal Of Mathematics Science And } \\
\text { Technology Education }\end{array}$ & 8 & Sexuality And Disability & 2 \\
\hline Quality And Quantity & 3 & $\begin{array}{l}\text { World Academy Of Science Engineering And } \\
\text { Technology }\end{array}$ & 2 \\
\hline Studies In Health Technology And Informatics & 8 & Yeni Symposium & 2 \\
\hline Advances In Environmental Biology & 4 & Acta Orthopaedica Et Traumatologica Turcica & 2 \\
\hline $\begin{array}{l}\text { American Journal Of Agricultural And } \\
\text { Biological Science }\end{array}$ & 4 & Other 89 Journals each one 1 paper & 89 \\
\hline
\end{tabular}

\subsection{Distribution by Country}

The distribution of articles by country name where authors collected data is shown in Table 4. At the country level, the Middle East Countries (MEC) is 17 countries were represented from, and the most frequently studied countries were Turkey (79), Iran
(35), Israel (29), Saudi Arabia (28), Cyprus (9), Egypt (8), United Arab Emirates (4), Jordan and Oman for each (3), Lebanon (2), and finally, Bahrain, Iraq, Kuwait, Qatar, Syrian Arab Republic and Yemen for each country is 1 study. See Table 4 and Figure 5.

Table 4: Distribution by Country

\begin{tabular}{|l|c|l|c|}
\hline Country & Article Count & Country & Article Count \\
\hline Turkey & 79 & Lebanon & 2 \\
\hline Iran & 35 & Bahrain & 1 \\
\hline Israel & 29 & Iraq & 1 \\
\hline Saudi Arabia & 28 & Kuwait & 1 \\
\hline Cyprus & 9 & Qatar & 1 \\
\hline Egypt Arab & 4 & $\begin{array}{l}\text { Syrian Arab } \\
\text { Republic }\end{array}$ & 0 \\
\hline $\begin{array}{l}\text { United } \\
\text { Emirates }\end{array}$ & 3 & Yemen & 1 \\
\hline Jordan & 3 & Total & 0 \\
\hline Oman & & \multicolumn{2}{|l}{} \\
\hline
\end{tabular}

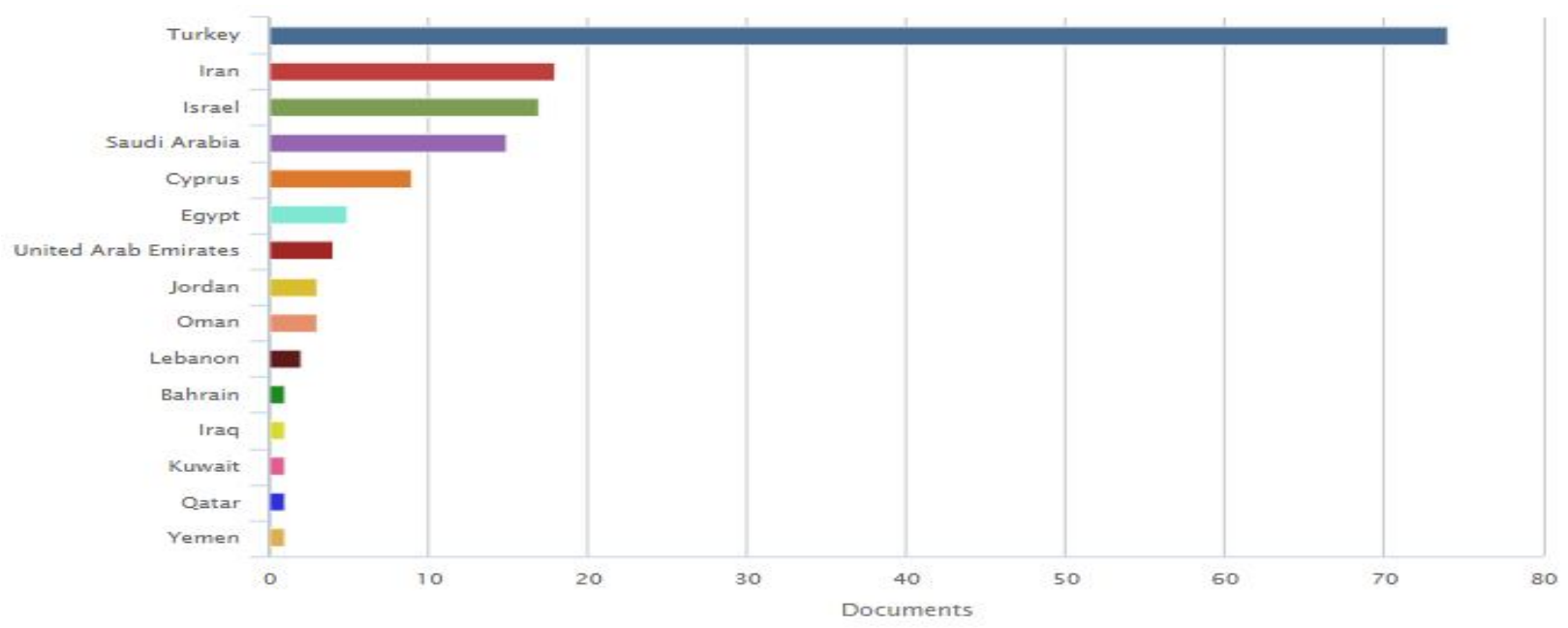

Figure 5: Distribution by Country

\subsection{Distribution by the type}

Table 5and Figure 6shows that most of the studies were from Articles with 163 percentages, and conference papers with 28 percentages. The next review papers with 8 percentages, article in press with 3 percentages, book chapter with 2 percentages, and final editorial study with 1 percentage. Noted that high percentageof studies were an articles and conference papers.

Table 5: Distribution by the type

\begin{tabular}{|l|c|l|c|}
\hline \multicolumn{1}{|c|}{ Document Type } & Documents & \multicolumn{1}{c|}{ Document Type } & Documents \\
\hline Article & 163 & Article in Press & 3 \\
\hline Conference Paper & 28 & Book Chapter & 2 \\
\hline Review & 8 & Editorial & 1 \\
\hline
\end{tabular}




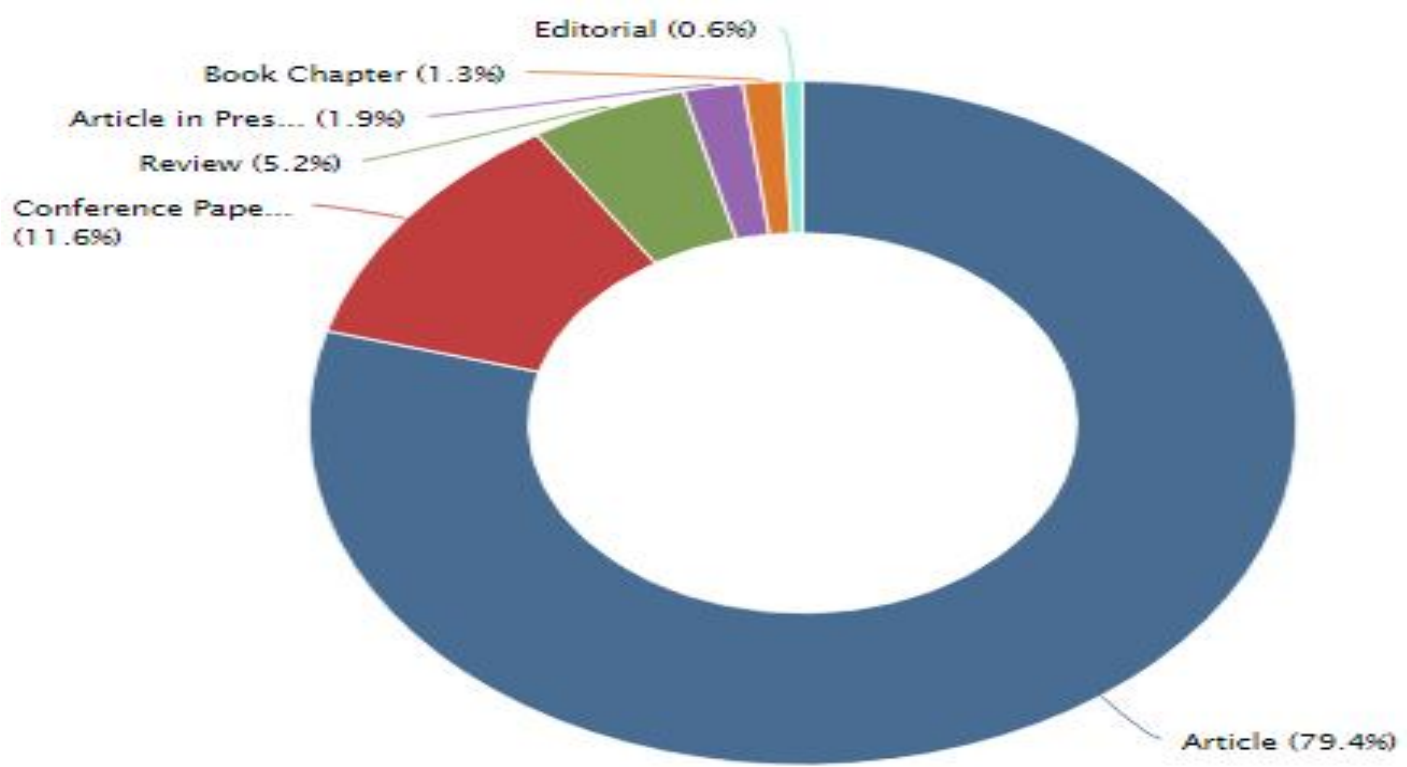

Figure 6: Distribution by the type

\subsection{Distribution by subject area}

Table 6 shows the distribution by the subject area noted most of the studies were from social sciences area 58articles, and computer science area 43articles, and medicinearea articles. the next studies from engineering area with 12articles,and arts and humanities area with 10 articles, and 9 articles were from mathematicsarea, also, psychology area 8 articles. Moreover, agricultural and biological sciences also health professions for each one 7 articles. The next nursing area 6 articles, Business, management and accounting science area 5 articles, Similarly, neuroscience area 5 articles. The next area biochemistry, genetics and molecular biology were 3articles; also, decision sciences were 3 articles). Moreover, the four areas such as economics, econometrics and finance, environmental science, multidisciplinary, and pharmacology, toxicology and pharmaceutics were 2articles. Finally, tow area are immunology and microbiology, and physics and astronomy were 1 study for each one article.

Table 6: Distribution by subject area

\begin{tabular}{|l|l|c|}
\hline No & \multicolumn{1}{|c|}{ Subject Area } & Documents \\
\hline 1 & Social Sciences & 58 \\
\hline 2 & Computer Science & 43 \\
\hline 3 & Medicine & 19 \\
\hline 4 & Engineering & 12 \\
\hline 5 & Arts and Humanities & 10 \\
\hline 6 & Mathematics & 9 \\
\hline 7 & Psychology & 8 \\
\hline 8 & Agricultural and Biological Sciences & 7 \\
\hline 9 & Health Professions & 7 \\
\hline 10 & Nursing & 6 \\
\hline 11 & Business, Management and Accounting & 5 \\
\hline 12 & Neuroscience & 5 \\
\hline 13 & Biochemistry, Genetics and Molecular Biology & 3 \\
\hline 14 & Decision Sciences & 2 \\
\hline 15 & Economics, Econometrics and Finance & 2 \\
\hline 16 & Environmental Science & 2 \\
\hline 17 & Multidisciplinary & 2 \\
\hline 18 & Pharmacology, Toxicology and Pharmaceutics & 1 \\
\hline 19 & Immunology and Microbiology & 1 \\
\hline 20 & Physics and Astronomy & 205 \\
\hline & Total & 3 \\
\hline
\end{tabular}




\subsection{Empirical Research}

Our analysis shows that most of the studies were from quantitative research by survey with 159 , and an interview was9. And finally, mixed methods approach with 37. Thus, the total of quantitative research was a high level with 159articles. Table 7 shows the results of our classification in empirical research.

Table 7: Empirical research approaches used to study IS continuance intention

\begin{tabular}{|l|c|c|c|}
\hline \multicolumn{1}{|c|}{ Research Approach } & Methods Used & Article Count & Percentage \\
\hline Quantitative Research & Survey & 159 & 70.3 \\
\hline Qualitative Research & Interviews & 9 & 5.8 \\
\hline Mixed methods & Survey and Interviews & 37 & 23.9 \\
\hline \multicolumn{2}{|c|}{ Total } & $\mathbf{2 0 5 5}$ & $\mathbf{1 0 0 . 0}$ \\
\hline
\end{tabular}

\section{DISCUSSION AND IMPLICATIONS}

According to $[3,7,35]$ found that social media used has a positive influence for collaborative learning and engagement. Also, more detailed studies like[9], reported direct and indirect significant impacts of these variables on collaborative learning through the use of social media which might lead to a better performance by learners.Another study by [19] found that students are satisfaction for social media used for educational purposes. On the other hand, [16] reported that research students use social media for learning which has negative effect on their concentration like time spent. As the level of attention increases, the amount of time spent on social media is greater than before, implying that there is an increased level of attention which has a negative influence on their academic achievement [36]. Similarly, the results showed that the negative relationship between social media use and GPA was moderated by multitasking and the waste of time in the US sample. This may be due to European students being less prone to multitasking [16]. On the other cam, [22]reported a positive influence of social media used on student'sinteractions that were surveyed for their opinions. Institutions and universities that offer SM know exactly these advantages and that is why they keep encouraging and inviting students into these courses. Thus, this study might be important to them giving them more systematic literature review in higher education of Middle East Countries (MEC) on social media used for educational purposes. Moreover, Active collaborative learning can occur on social media, as they can be used to help individuals work together to complete a collective objective [11, 19]. In addition to this, social media use facilitates positive relationship between the learning performance and satisfaction of research students [12,7]. Furthermore, $[13,9]$ reported a positive relationship between students learning performance and SM usage.Some models and frameworks of social media have many significant negative impacts on student engagement, active collaborative learning and learning performance $[12,16]$. In contrast, some models and frameworks of social media have many significant positive impacts on student engagement, active collaborative learning and learning performance [13, 27, 37].In addition, few researchers in Middle East Countries (MEC) have conducted studies on social media used for educational purposes with different perspectives and theories. Therefore, this study is important and will an extensive and systematic review of literature concerning social media used among universities' students in higher education of Middle East Countries (MEC).Unfortunately, the process of learning through social media use is lacking the feature of team and group work which is vital to the learning environment. These notions of group and team work are not supported via social media platforms and that is why instructors and teachers resort to third party platforms. Thus, as researchers working in this field are responsible for improving the kind of learning and look for solutions to the different problems.

\subsection{Future Research}

Future studies should consider this information to extend the existing literature in Middle East Countries (MEC) and elsewhere. This study also suggests the development a models and frameworks for using social media in higher education of Middle East Countries (MEC) and other countries. The current study recommends that future research should utilize more elements to measure the various factors that might influence learning using social media like interactivity, collaborative learning and engagement among learners. Also, a growing number of researches are conducted in an attempt to better understand the issue of the dropouts in SM and on the same time, researchers are trying to improve the effectiveness of social media use in higher education of Middle East Countries (MEC).

\subsection{Conclusion}

This research provided a general picture of the present state of using social media use in higher education of Middle East Countries (MEC) through conducting a systematic review of 205 papers throughout 112 journals from 1999 to 2020. The researchers specifically conducted an analysis of contributions in light of the research questions developed that covered the year of publication, 
research methods, journals, authors, countries, type of study area and the theories employed. The contributions were classified in a systematic manner to provide a general picture of using social media in higher education of Middle East Countries (MEC) for educational purposes and to assist researchers in searching for important studies in this area. Moreover, this research contributes to materials required by readers who are interested in different aspects related to the literature of using social media for educational purposes in higher education of Middle East Countries (MEC). Furthermore, many theories were utilized in this research for the enhancement of social media used through highlighting the five concepts of intention to use, interaction, engagement, motivations and satisfaction. In summary, confirm that students' academic performance can be influenced by social media tools on positively, and social media tools which have the advantage of facilitating the learning process through offering materials and enabling the share of knowledge and information among student.

\section{ACKNOWLEDGMENT}

The author acknowledges the Deanship of Scientific Research at King Faisal University.

\section{REFERENCES}

1. Y. Al-Saggaf, and P. Simmons. Social media in Saudi Arabia: Exploring its use during two natural disasters. Technological Forecasting and Social Change, 95, 2015, pp 3-15. https://doi.org/10.1016/j.techfore.2014.08.013

2. C. Sibona. and J. Choi. Factors Affecting EndUser Satisfaction on Facebook. Proceedings of the Sixth International AAAI Conference on Weblogs and Social Media.2012.

3. W. M. Al-Rahmi, N. Yahaya, M. M. Alamri, I. Y. Alyoussef, A. M. Al-Rahmi, and Y.B. Kamin. Integrating innovation diffusion theory with technology acceptance model: supporting students' attitude towards using a massive open online courses (MOOCs) systems. Interactive Learning Environments, 2019, pp113.

https://doi.org/10.1080/10494820.2019.1629599

4. S.I. Alsanie. Social Media (Facebook, Twitter, WhatsApp) Used, and its Relationship with the University Students Contact with their Families in Saudi Arabia. Universal Journal of Psychology, 3(3), 2015, pp 69-72. https://doi.org/10.13189/ujp.2015.030302

5. H. Ajjan, and R. Hartshorne. Investigating faculty decisions to adopt web 2.0 technologies: Theory and empirical tests. The Internet and Higher Education, 11, 2008, pp 7180.

https://doi.org/10.1016/j.iheduc.2008.05.002
6. R. Junco, G. Heiberger, and E. Loken. The effect of Twitter on college student engagement and grades. Journal of Computer Assisted Learning, 27(2), 2011, pp 119-132.

7. W. M. Al-Rahmi, N. Yahaya, A.A. Aldraiweesh, U, Alturki, M.M. Alamri, M. S. B. Saud, Y.B. Kamin, A.A. Aljeraiwi, and O.A. Alhamed. Big Data Adoption and Knowledge Management Sharing: An Empirical Investigation on their Adoption and Sustainability as a Purpose of Education. IEEE Access, 7, 2019, pp4724547258.

8. E. Alwagait, B. Shahzad, and S. Alim. Impact of social media usage on students' academic performance in Saudi Arabia. Computers in Human Behavior, 51, 2015, pp 1092-1097.

https://doi.org/10.1016/j.chb.2014.09.028

9. W. M. Al-Rahmi, N. Alias, M.S. Othman, I.A. Ahmed, A.M. Zeki, and A.A. Saged. Social Media Use, Collaborative Learning and Students' academic Performance: A Systematic Literature Review of Theoretical Models. Journal of theoretical \& applied information technology, 95(20), 2017.

10. Y. Yang, Q. Wang, H.L. Woo, and C.L. Quek. Using Facebook for teaching and learning: a review of the literature. International Journal of Continuing Engineering Education and LifeLong Learning, 21(1), 2011, pp 72-86.

11. R. Cheung, and D. Voge. Predicting user acceptance of collaborative technologies: An extension of the technology acceptance model for e-learning. Computers \& Education, 63, 2013, pp 160-175.

https://doi.org/10.1016/j.compedu.2012.12.003

12. N. Agarwal, M. Lim, and R.T. Wigand. Online collective action and the role of social media in mobilizing opinions: A case study on women's right-to-drive campaigns in Saudi Arabia. In Web 2.0 technologies and democratic governance (pp. 99-123). Springer, New York, NY, 2012.

13. S. Ainin, M.M. Naqshbandi, S. Mogavvemi, and N.I. Jaafar. Facebook usage, socialization and academic performance. Computers \& Education. 83, 2015, pp 64-73.

14. A.K. Alsuraihi, A. S.Almaqati, S.A.Abughanim, and N.A.Jastaniah. Use of social media in education among medical students in Saudi Arabia.Korean journal of medical education, 28(4), 2016, 343.

https://doi.org/10.3946/kjme.2016.40

15. Q. Wang, H.L. Woo, C.L. Quek, Y. Yang, and M. Liu. Using the Facebook group as a learning management system: An exploratory study. British Journal of Educational Technology, 43(3), 2012, pp 428-438.

16. S. Bahkali, A.Almaiman, A.Bahkali, S.Almaiman, M.S.Househ, and K. Alsurimi. The 
Role of Social Media in Promoting Women's Health Education in Saudi Arabia. In ICIMTH, 2015, pp. 259-262.

17. N. Mohamed, and H. Ahmad.Information privacy concerns, antecedents and privacy measure use in social network sites. Computer in Human Behavior, 28(6), 2012, pp 2366-2375.

18. W. Lee. Exploring the behavioral aspects of adopting technology: Meeting planners' use of social network media and the impact of perceived critical mass. Journal of Hospitality and Tourism Technology, 4(1), 2013, pp 6-22.

19. M.M. Alamri. Students' academic achievement performance and satisfaction in a flipped classroom in Saudi Arabia. International Journal of Technology Enhanced Learning, 11(1), 103-119, 2019.

20. M.K. Kabilan, N. Ahmad, and M.J.Z. Abidin. Facebook: An online environment for learning of English in institutions of higher education?The Internet and Higher Education, 13(4), 2010, pp 179-187.

https://doi.org/10.1016/j.iheduc.2010.07.003

21. B.L. Arcas, I. Buil, B. Hernández-Ortega, and F.J. Sese. Using clickers in class. The role of interactivity, active collaborative learning and engagement in learning performance. Computers \& Education, 62, 2013, pp 102-110.

22. W. M. Al-Rahmi, N. Yahaya, M.M. Alamri, N.A. Aljarboa, Y.B. Kamin, and F.A. Moafa. A Model of Factors Affecting Cyber Bullying Behaviors among University Students. IEEE Access, 7, 2018, pp 2978-2985.

23. C. Shirky. Cognitive surplus: How technology makes consumers into collaborators. New York, NY: Penguin Press, 2011.

24. Abuhassna, M. A. Z. M. Zakaria, N. Yahya, A. MohdKosnin, and W. M. Al-Rahmi. Examining Students' Satisfaction and Learning Autonomy through Web-Based Courses. International Journal of Advanced Trends in Computer Science and Engineering, vol. 9, no. 9, pp. 356-370, 2020.

https://doi.org/10.30534/ijatcse/2020/53912020

25. M. Farwell, and D. Waters. Exploring the Use of Social Bookmarking Technology in Education: An Analysis of Students' Experiences using a Course-specific Delicious. Com Account, 6, 2010, pp 1-12.

26. M. Kaplan, and M. Haenlein. Users of the world, unite! The challenges and opportunities of Social Media. Business Horizons, 53(1), 2010, pp 59-68.

27. M. Mahdi. Undergraduate Students' Perceptions toward Social Media Usage and Academic Performance: A Research from Saudi Arabia. International Journal of
Emerging Technologies in Learning, 14(3), 2019.

https://doi.org/10.3991/ijet.v14i03.9340

28. E. Novak, R. Razzouk, and E. Johnson. The educational use of social annotation tools in highereducation: A literature review. The Internet and Higher Education, 15(1), 2012, pp 39-49.

https://doi.org/10.1016/j.iheduc.2011.09.002

29. S. Ouhrir, S. Lotfi, and M. Talbi. Students' Views on E-learning and Knowledge of Learning Platforms: Case of a Professional License at the Higher Normal School of Casablanca. International Journal of Advanced Trends in Computer Science and Engineering, vol. 8, no. 5, pp. 2282-2288, 2019. https://doi.org/10.30534/ijatcse/2019/66852019

30. L.S. Vygotsky. Mind in society: The development of higher psychological processes. Cambridge, MA: Harvard University Press, 1978.

31. E. Makki, and L.C. Chang. Understanding the effects of social media and mobile usage on ecommerce: an exploratory study in Saudi Arabia. International management review, 11(2), 98, 2015.

32. F.D. Davis. Perceived usefulness, perceived ease of use and user acceptance of information technology. MIS Quarterly, 13, 1989, pp 319-340. https://doi.org/10.2307/249008

33. W.M. Al-Rahmi, and A.M. Zeki. A Model of Using Social Media for Collaborative Learning to enhance learners' Performance on learning. Journal of King Saud UniversityComputer and Information Sciences, 29 (4), 2017, pp 526-535.

34. S. Hrastinski, and M. Aghaee. How are campus students using social media to support their studies? An explorative interview study. Education and Information Technologies, 17(4), 2011, pp 451-464.

35. W. Al-Rahmi, A. Aldraiweesh, N. Yahaya, Y. B. Kamin, and A. M. Zeki. Massive open online courses (MOOCs): Data on higher education. Data in brief, 22, 118-125, 2019. https://doi.org/10.1016/j.dib.2018.11.139

36. A. Paul, M. Baker, and D. Cochran. Effect of online social networking on student academic performance. Computers in Human Behavior, 28(6), 2012, pp 2117-2127.

37. W. M. Al-Rahmi, N. Yahaya, M.M. Alamri, N.A. Aljarboa, Y.B. Kamin, and M.S.B. Saud. How Cyber Stalking and Cyber Bullying Affect Students' Open Learning. IEEE Access, 7, 2019 https://doi.org/10.1109/ACCESS.2019.2891853 